\title{
Salience in the Media and Political Trust in Nigeria: The Mediating Role of Political Participation
}

\author{
Oladipupo Abdullahi Akinola ${ }^{1,2}$, Bahiyah Omar ${ }^{*}$ and Lambe Kayode Mustapha ${ }^{3}$ \\ ${ }^{1}$ School of Communication, Universiti Sains Malaysia, 11800 Gelugor, Penang, Malaysia \\ ${ }^{2}$ Department of General Studies, Federal Polytechnic Ede, 232101, Ede, Nigeria \\ ${ }^{3}$ Department of Mass Communication, University of Ilorin, 240 003, Ilorin, Nigeria
}

\begin{abstract}
Political distrust is prevalent in many parts of the world. Scholars have discovered many factors affecting political trust, but they have paid little attention to the influence of issue salience in the media on political trust. Focusing on the role of media in assigning salience to corruption issues in Nigeria, this study examined the influence of mainstream media and social media on political trust. In addition, we treated political participation as a mediating factor and investigated its effect on the relationship between perceived salience of corruption in media and political trust. A survey was conducted on a sample of 688 Nigerians aged above 18 years old using a multi-stage cluster sampling technique. The data was later analyzed using Partial Least Square-Structural Equation Modelling (PLS-SEM). We found that salience in media predicted political trust, and the effect was stronger for social media than mainstream media contexts. Our findings also suggested that political participation directly affected political trust and was a significant mediator that affected the relationships between salience in the mainstream media (SMM) and political trust and between salience in the social media (SSM) and political trust. The results imply that salience in media leads to political participation, leading to political trust. This study supports the assumptions of both agenda-setting and agenda-melding

ARTICLE INFO

Article history:

Received: 15 March 2021

Accepted: 25 June 2021

Published: 05 November 2021 theories. It suggests that policymakers in Nigeria should adopt media, especially social media, to restore the people's trust in government.
\end{abstract}

DOI: https://doi.org/10.47836/pjssh.29.4.03

E-mail addresses:

Oladipupo7@gmail.com (Oladipupo Abdullahi Akinola)

bahiyah@usm.my (Bahiyah Omar)

muslakay@yahoo.co.uk (Lambe Kayode Mustapha)

* Corresponding author
Keywords: Corruption, political participation, political trust, salience in the media 


\section{INTRODUCTION}

Political trust, which is described as confidence in government, is one of the key resources for the development of modern societies because it is critical to democratic governance (Wang, 2016). It is the support for government, parliaments, political parties, or political institutions that can be regarded as an evaluative orientation of citizens towards their political system or some part of it, based on their normative expectations (Hetherington, 1998; Wang, 2016). Consequently, the trust between citizens and their elected representatives and government officials is fundamental for liberal democracy and is a vital element of a well-governed society (Allen, 2016; Berg, 2019). Without political trust, citizens become cynical about their political system and disaffected with the existing order (Kumar et al., 2020). However, building support for democratic government depends on how much citizens trust their government to do right. Newton et al. (2018) and Wang (2016) contend that a democratic society cannot probably emerge without political trust, leading to the loss of political power by the incumbents.

However, previous studies have discovered that the majority of the citizens around the world distrust their governments (Allen, 2016; Ceron, 2015; Wang, 2016). The declining trend of political trust is evident in the United States, United Kingdom, other Western democratic nations, and many Asian and African nations (Camaj, 2014). This trend is also prevalent in Nigeria, which has consistently faced many problems, particularly high corruption levels that deteriorates political trust. Corruption in Nigeria is endemic, so much so that its pervasiveness has led to a high poverty rate, miserable economic performance, and low national development. Moreover, scholars claim that corruption has continued to threaten the unity, stability, and peace of the nation (Ogbeidi, 2012; Okafor et al., 2020) and has severely undermined people's trust in institutions and political systems in general (Iroghama, 2012). Inevitably these issues have become the media's focus, including mainstream and social media platforms in Nigeria. By giving salience to corruption, this study argues that the media can shape people's opinions about an issue eventually affecting their participation and trust in the government.

Unlike previous studies that investigated the effect of social media on political participation (Dagona et al., 2013; Mustapha \& Omar, 2020), we focused on the effect of corruption salience by mainstream and social media on political trust in Nigeria and the mediating effects of political participation on the relationship between salience in media and political trust. It is important to note that most past studies examining media influence on political trust were carried out in western contexts (Camaj, 2014; Ceron, 2015), with a few studies conducted in Asian nations (Wang, 2016; Wilkes, 2015). Thus, investigating it in another context like Nigeria, a multilingual, multi-ethnic, multireligious, and multi-party nation, is a welcome development (Camaj, 2014; Iroghama, 2012). Moreover, the study 
findings can give insights into addressing the precarious problems of insecurity, noncompliance with the law by the citizens, and other socio-political problems that arose due to low political trust among Nigerians.

In doing so, we developed a model drawn from agenda-setting and agendamelding perspectives to demonstrate the influence of mainstream media and social media, respectively. The model was further extended by introducing political participation as a mediator between salience in media and its relation to political trust. The novelty of this study is the extension of literature on agenda-setting as the theory of media's effect to agenda-melding, which is a new theoretical preoccupation being adopted to explain social media effect on political trust. We argue that while agenda-setting declared that mass media effectively sets the agenda for the people and government, thereby influencing the salience of attitude towards political outcomes by determining the news items readers should read (Mustapha \& Wok, 2015), agenda-melding assumes that it is the audience which set the agenda for the government and the people (Allen, 2016). In other words, agenda-melding maintains that the audience is active participants who initiate and produce news to influence people's opinion through the news items they produce, modify, like, and share with other readers (McCombs et al., 2014; Ragas $\&$ Roberts, 2009). Hence this new media theory claims that unlike mainstream media, where the audience is perceived as passive participants, they are active and major agenda setters (Bantimaroudis et al., 2020).
Furthermore, the limited literature on the effect of media salience on political trust has prompted this research to extend the investigation on political trust by examining mainstream media and social media as determinants of political trust and political participation as factors that mediated the relationship between media salience and political trust. We assumed that citizens' exposure to corruption that the media have given news salience would affect their participation in politics, eventually affecting their levels of trust in the incumbent government.

\section{LITERATURE REVIEW}

\section{Theoretical Framework}

In this study, two theoretical lenses, agenda-setting, and agenda-melding, were adopted to explicate the effect of salience in traditional mainstream media and social media. The two theories are interconnected but distinguished by their contexts (Bantimaroudis et al., 2020; McCombs et al., 2014). While agenda-setting involves how mass media determine what the people read and think about government, agendamelding sees the audience as a major stakeholder in news production and sharing. Agenda melding submits that mass media no longer has the monopoly of news production and the only opinion molder. Thus, agenda setting research emphasizes how the media consciously transfer the salience to specific issues to set the public agenda (McCombs \& Shaw, 1972). In other words, through the gatekeeping process, journalists manipulate audience opinion to set agendas for the 
people and consequently for the government (McCombs et al., 2014). Furthermore, through the press's priming and framing activities, the media indirectly informs the audience what to think and tells them how to think about it (Hänggli, 2020).

Kiousis (2011) asserts that the theoretical assumption of the agendasetting theory is the transferring of salience from the media to the people by presenting news items to influence audience opinions (McCombs \& Shaw, 1972; McCombs et al., 2014; Mustapha \& Wok, 2015). The theory assumes that the audience is passive. The media feeds them the news and therefore influences their opinion through the quantity, prominence, and attention given to issues (McCombs \& Shaw, 1972). The theory is often applied to understand how media organizations dictate what people should think about. The emergence of new media has called for renewed attention to the relationships between old and new media (Omar, 2017) and the introduction of new theories to understand a new phenomenon (Siapera, 2017). Agenda melding is one of the new theories that emanates from the agenda-setting theory (Bantimaroudis et al., 2020; Cheng, 2021: McCombs et al., 2014; Woo et al., 2020). It provides an insight into how the audience, rather than being passive as explicated by agenda-setting, is active. Social media users become producers and presenters of news. Thus, in this age of digital, audiences now, from their personal views, intentionally decide, initiate, select, comment, frame, like, salience, create and share news items to modify people's political opinion and therefore set national agendas (Allen, 2016; McCombs et al., 2014; Ragas \& Roberts, 2009).

Through the agenda-melding process, social media users gather various agendas to create the "personal communities" in which the users willingly choose to live (Allen, 2016; McCombs et al., 2014). Unlike agenda-setting theory, where the media gatekeeping the news items deliberately and select news issues to influence people's opinion, agenda-melding theory gives the audience opportunities to initiate and create the public and media agenda. Concerning media use and political trust, past research confirmed a positive relationship between mainstream media and political trust (Camaj, 2014). Drawing from the views of previous researchers and the perspective of both agenda-setting and agenda-melding theories, we contend that the media effect which arises from the way and manner through which mass media and social media users used the gatekeeping process to intentionally influence the opinion of the audience on their political decisions. Consequently, this study adopted agendasetting and agenda-melding media effect elements to explain media use as a strong determinant of political trust. Adopting the agenda-setting and agenda-melding is expected to broaden our understanding of political trust within a Nigerian context.

\section{Hypothesis Development}

Salience in the Media and Political

Participation. Media is a vital source of influence on political trust. This study 
developed a research model depicting the relationship between media salience, political participation, and political trust (see Figure 1). Both mainstream and social media use for political news reinforces political participation by playing an essential role in bringing the politicians and the generality of the people together (Kiousis, 2004; Mustapha \& Omar, 2020). Through the media, people are informed, educated, and influenced politically. Supporting this assertion, Krishna and Jha (2017) noted that mass media like radio, television, and newspaper impact people's socio-political lives. They disseminate political information upward or downward (Echeverría \& Mani, 2020). Färdigh (2013) and Park (2012) maintained that through framing corruption issues in certain ways and assigning salience to them, the media influence people's opinions about the menace of corruption. Media can shape and influence people's opinions, attitudes, behaviors and perceptions towards political leaders and political activities by giving prominence to certain issues and ignoring others (Kiousis, 2004). By exposing the corrupt activities of the politicians, the media helped increase society's political knowledge and behavior at large (Aarts et al., 2012). In addition, past studies have consistently found that social media use predicted political participation (Gil de Zúñiga et al., 2014; Shahzat \& Omar, 2021). Extending past studies that mainly focused on general media use or social media use per se, we examined the degree of salience given by mainstream media and social media on corruption and how it affected people's trust in politics. Hence, we hypothesize that:

H1: Salience in the mainstream media is positively associated with political participation.

H2: Salience in social media is positively associated with political participation.

\section{Political Participation and Political}

Trust. Democratic governments perform better when the people understand and trust the government. Political trust facilitates talking and working together among individuals and between the public and the government (Wilkes, 2015). Generally, the level of political trust depends on the individual objective evaluation of government performance. Jacob and Schenke (2020) claimed that regardless of media exposure intensity to poor governance of the incumbent government, members of the ruling party can hardly believe that the government is bad and can easily feel satisfied with their performance, unlike those in the opposition party. Thus, an individual with party affiliation generally believes that a party they associate with performs more effectively and efficiently than other parties (Jacob \& Schenke, 2020; Wilkes, 2015). Regarding the possible relationship between political participation and political trust, past studies (Bonifácio \& Paulino, 2015; Wilkes, 2015) found that party affiliation, tolerance, for and experience with corruption determined people's trust in the incumbent government. Hence, we propose that: 
H3: Political participation is positively associated with political trust.

\section{Media Use, Political Participation, and}

Political Trust. There is an interdependence between politics and media. Skamnakis (2006) argued that since 1960, politics and media do not only continue to have a close relationship, but they are interdependent. Media provides a platform for articulation and contestation of viewpoints that assists the audience to make an informed decision on their political activities (Mustapha \& Wok, 2015) and solidify or reduce their support in the government (Kleinnijenhuis et al., 2020). This study asserts from media salience literature, that the volume, placement, and valence of issues are necessary to produce media effects. Past research has established the effects of media use on political participation (Gil de Zúñiga et al., 2014; Shahzad \& Omar, 2021) and political trust (Aarts et al., 2012). A few studies also found the association between political participation and political trust (Bonifácio \& Paulino, 2015; Wilkes, 2015). Linking these studies together, we argue that salience in media leads to political participation, which in turn leads to political trust. Hence, we treat political participation as a mediator and hypothesize that:

H4: Political participation mediates the relationship between salience in the mainstream media and political trust.

H5: Political participation mediates the relationship between salience in social media and political trust.

\section{METHOD}

This study, based on a survey research method, focuses on Nigerian electorates 18 years and above. In Nigeria, the political structure of six geopolitical zones, 36 states, and 774 local governments make the country a complex one (Mustapha \& Wok, 2015). As a result of the country's complex political structure, the study adopted a multistage sampling technique to obtain a representative sample from the population. A questionnaire was used to gather information from the respondents. We used the $G^{*}$ power to determine the minimum sample size of 77 , with three predictors, medium effect size, and a power of 0.80 . However, the sample size was increased to 688 since we are dealing with

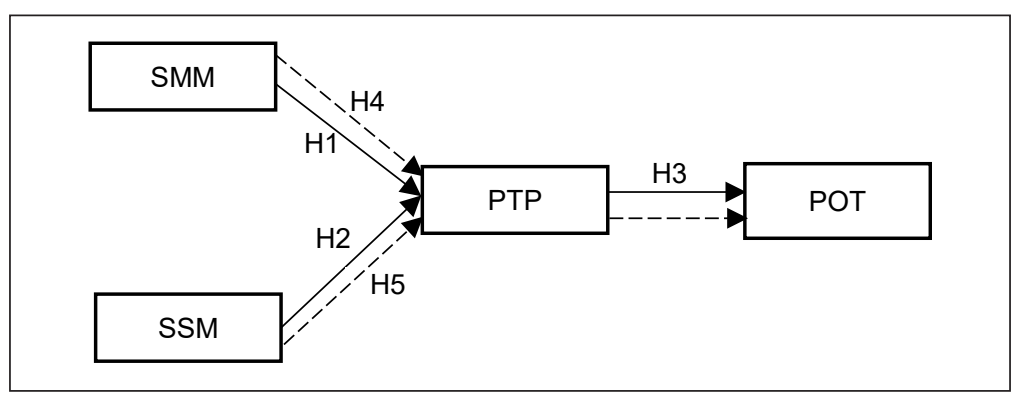

Figure 1. Research model

Note: $\mathrm{SSM}=$ Salience in the Social Media; $\mathrm{SMM}=$ Salience in the Traditional Mainstream Media, $\mathrm{PTP}=$ Political Participation, POT $=$ Political Trust 
a heterogeneous population. Some scholars (Baltar \& Brunet, 2012; Omar \& Ahrari, 2020) suggested a comparison of the study sample with the national demographic statistics to achieve generalizability and increase the sample's representativeness. Therefore, a questionnaire was administered to 688 respondents in the 36 states and 774 local governments that make up the six geopolitical zones in Nigeria. As shown in the demographic profile in Table 1, it could be inferred that the sample of this study is almost similar to the demographic data of the Nigeria National Bureau of Statistics (NBS, 2017). Thus, the sampling bias in the current study was minimized.

This study sample comprises 688 Nigerians above 18 years old. Since the minimum voting age in Nigeria is 18 , anyone below the voting age was disqualified from participating in this study. The data was collected in February 2019, before the country's general election. As indicated in the table, more males $(59.3 \%)$ than female respondents (40.7\%). The highest age category was between 18 and $34(64.5 \%)$. In relation to education levels, most respondents of this study possessed Bachelor or Higher National Diploma (HND) degree (56.3\%), followed by Diploma certificates (23.4\%), master's degree (12.8\%), and Ph.D. (2.6\%). This analysis indicated that the majority of respondents were young educated Nigerians. The distribution of respondents according to geopolitical zones shows that the number of respondents across all zones was almost equal. In terms of government support, more than half of the respondents $(57.1 \%)$ indicated their support, while the rest (42.9) did not identify as supporters of the current government in power.

\section{Measurement}

This study has four constructs. First, we treat salience in mainstream media and social media as independent variables, political participation as the mediating variable, and political trust as the dependent variable. Second, all items were adopted from past studies. The items were adapted from past studies (Schneider, 2017), while political participation was adopted from Huddy et al. (2010). Third, we adopted the salience in media for both traditional mainstream media and social media contexts from the work of Kiousis (2004). They used content analysis to derive a few themes of media silence. Finally, we developed statements from the themes and tested them empirically in this study. The variables were measured based on a 7-point Likert scale ranging from $1=$ Strongly Disagree and $7=$ Strongly Agree. Three experts of political communication were consulted to validate the study's items. A pilot study was also conducted to improve the questionnaire. Based on the contributions of the experts and the feedback from the pilot study, the instrument was amended and reworded to enhance its richness and clarity.

\section{FINDINGS}

To analyze our model, we used Partial Least Squares - Structural Equation Modelling (PLS-SEM) to allow us to examine relationships between constructs 
Table 1

Respondents'demographic profile

\begin{tabular}{|c|c|c|}
\hline Demographic Factors & Freq. & Pert \\
\hline \multicolumn{3}{|l|}{ Gender } \\
\hline Male & 408 & 59.3 \\
\hline Female & 280 & 40.7 \\
\hline \multicolumn{3}{|l|}{ Age } \\
\hline $18-24$ years & 168 & 24.5 \\
\hline $25-34$ years & 275 & 40 \\
\hline $35-44$ years & 119 & 17.3 \\
\hline $45-54$ years & 85 & 12.4 \\
\hline $55-64$ years & 34 & 4.9 \\
\hline 65 years and above & 7 & 1 \\
\hline \multicolumn{3}{|l|}{ Marital Status } \\
\hline Single & 363 & 52.8 \\
\hline Married & 314 & 45.6 \\
\hline Others & 11 & 1.6 \\
\hline \multicolumn{3}{|l|}{ Level of Education } \\
\hline Do not Attend School & 1 & 0.1 \\
\hline Primary School & 5 & 0.7 \\
\hline Secondary School & 28 & 4.1 \\
\hline Diploma & 161 & 23.4 \\
\hline Bachelor /HND & 387 & 56.3 \\
\hline Masters & 88 & 12.8 \\
\hline $\mathrm{PhD}$ & 18 & 2.6 \\
\hline \multicolumn{3}{|l|}{ Income $(\mathbf{N})$} \\
\hline Up to 18,000 & 198 & 28.8 \\
\hline $18001-30,000$ & 112 & 16.3 \\
\hline $30,001-50,000$ & 138 & 20.1 \\
\hline $50,001-70,000$ & 68 & 9.9 \\
\hline $70,001-100,000$ & 94 & 13.7 \\
\hline Above 100,000 & 78 & 11.3 \\
\hline \multicolumn{3}{|l|}{ Types of Employment } \\
\hline Self & 268 & 39 \\
\hline Government & 253 & 36.8 \\
\hline Unemployed & 167 & 24.3 \\
\hline \multicolumn{3}{|l|}{ Religion } \\
\hline Islam & 404 & 58.7 \\
\hline Christianity & 281 & 40.8 \\
\hline Others & 2 & 0.3 \\
\hline None & 1 & 0.1 \\
\hline \multicolumn{3}{|l|}{ Ethnicity (Geopolitical Zones) } \\
\hline Hausa (North Central, North East \& North West) & 345 & 50.1 \\
\hline Igbo (South East \& South-South) & 227 & 33 \\
\hline Yoruba (South West) & 116 & 16.9 \\
\hline \multicolumn{3}{|l|}{ Political Participation } \\
\hline African Action Congress (AAC) & 4 & 0.6 \\
\hline Action People's Congress (APC) & 245 & 35.6 \\
\hline All Progressive Grand Alliance (APGA) & 21 & 3.1 \\
\hline People's Democratic Party (PDP) & 196 & 28.5 \\
\hline Others (Parties) & 3 & 0.4 \\
\hline No (not belong to any party) & 219 & 31.8 \\
\hline \multicolumn{3}{|l|}{ Government Support } \\
\hline Yes & 393 & 57.1 \\
\hline No & 295 & 42.9 \\
\hline
\end{tabular}


simultaneously (Hair et al., 2019). PLSSEM is suitable for this study because the explanatory nature of our study and the normality tests shows our data was not normally distributed (as the results of the Shapiro-Wilk test of normality, Mardia test of multivariate normality, Skewness and Kurtosis were all significant). Since our data were collected in a single survey, we also checked for common method bias (CMB), using Harman's single factor test. The results showed that a single factor only explained $18.6 \%$ of the variance, suggesting that we do not have an issue with CMB since it does not exceed the threshold of $50 \%$. We also confirmed the variance inflation factor (VIF) and found that none were above the threshold of three (Hair et al., 2017) (Table 2). Therefore, we followed the two steps approach; first, we analyzed the measurement model and then tested the structural model.

\section{The Measurement Model}

In the measurement model, we established the validity and reliability of measures

Table 2

Measurement model assessment

\begin{tabular}{|c|c|c|c|c|c|c|}
\hline Construct & Items & Loadings & $\mathbf{C A}$ & CR & AVE & VIF \\
\hline \multirow{5}{*}{$\begin{array}{l}\text { Salience in the Traditional } \\
\text { Mainstream Media }\end{array}$} & SMM1 & 0.806 & 0.851 & 0.893 & 0.625 & 1.302 \\
\hline & SMM2 & 0.772 & & & & \\
\hline & SMM3 & 0.769 & & & & \\
\hline & SMM4 & 0.797 & & & & \\
\hline & SMM5 & 0.808 & & & & \\
\hline \multirow[t]{6}{*}{ Salience in the Social Media } & SSM1 & 0.784 & 0.888 & 0.915 & 0.643 & 1.302 \\
\hline & SSM2 & 0.852 & & & & \\
\hline & SSM3 & 0.845 & & & & \\
\hline & SSM4 & 0.795 & & & & \\
\hline & SSM5 & 0.78 & & & & \\
\hline & SSM6 & 0.749 & & & & \\
\hline \multirow[t]{5}{*}{ Political Participation } & PSP1 & 0.877 & 0.918 & 0.938 & 0.752 & 1.000 \\
\hline & PSP2 & 0.861 & & & & \\
\hline & PSP3 & 0.834 & & & & \\
\hline & PSP4 & 0.877 & & & & \\
\hline & PSP5 & 0.887 & & & & \\
\hline \multirow[t]{7}{*}{ Political Trust } & POT1 & 0.8 & 0.915 & 0.931 & 0.658 & - \\
\hline & POT2 & 0.816 & & & & \\
\hline & POT4 & 0.792 & & & & \\
\hline & POT5 & 0.736 & & & & \\
\hline & POT6 & 0.834 & & & & \\
\hline & POT7 & 0.871 & & & & \\
\hline & POT8 & 0.821 & & & & \\
\hline
\end{tabular}


before assessing the structural relationships in this study. Firstly, we determined the convergent validity by checking the Cronbach's alpha $(\alpha)$, average variance extracted (AVE), composite reliability (CR), and the loadings. As a result, the $\alpha$ values were above the threshold of 0.70 , AVE was above 0.50 , CR was above 0.70 , and the loadings were all above 0.70 (Hair et al., 2017), suggesting that the results satisfied the criteria for convergent validity and composite reliability (See Table 2).

Secondly, we tested the discriminant validity to establish the differences between variables. Two criteria (Fornell \& Larcker and HTMT) were used to determine discriminant validity. For the Fornell and Larcker criterion, Table 3 shows that each construct's AVE's square root surpassed the correlations with other constructs (Fornell \& Larcker, 1981). The results of the HTMT, as shown in Table 4, also demonstrates that none of the diagonal values were above the threshold of 0.85 (Ramayah et al., 2018). Thus, the criteria for discriminant validity were also met.

\section{The Structural Model}

In examining the structural model, scholars (Hair et al., 2014) recommended that researchers look at the $\mathrm{R}^{2}$, beta $\beta$, and t-values through a bootstrapping technique of 5000 samples. In addition to these basic steps, it was also suggested that the predictive significance $\left(\mathrm{Q}^{2}\right)$ and the effect sizes $\left(\mathrm{f}^{2}\right)$ should also be assessed. The structural equation model results are presented in Table 4 and Figure 2. The results show that $51 \%$ of the variance $\left(\mathrm{R}^{2}=0.51\right)$ in political participation is explained by the salience in mainstream media and salience in social media. Political participation, in turn, contributes to $35 \%$ of the variance in political trust $\left(\mathrm{R}^{2}=0.35\right)$. As shown in Table 5, all direct hypotheses were supported. Firstly, we found a positive relationship between

Table 3

Discriminant validity (Fornell-Larcker criterion)

\begin{tabular}{lcccc}
\hline & $\mathbf{1}$ & $\mathbf{2}$ & $\mathbf{3}$ & $\mathbf{4}$ \\
\hline 1. Political Participation & 0.867 & & & \\
2. Salience in the Social Media & 0.412 & 0.802 & & \\
3. Salience in the Traditional Mainstream Media & 0.346 & 0.482 & 0.791 & \\
4. Political Trust & 0.136 & 0.068 & 0.138 & 0.811 \\
\hline
\end{tabular}

Table 4

Discriminant validity (HTMT criterion)

\begin{tabular}{lcccc}
\hline & $\mathbf{1}$ & $\mathbf{2}$ & $\mathbf{3}$ & $\mathbf{4}$ \\
\hline 1. Political participation & - & & & \\
2. Salience in the Social Media & 0.454 & & & \\
3. Salience in the Traditional Mainstream Media & 0.385 & 0.551 & & \\
4. Political Trust & 0.138 & 0.091 & 0.169 & - \\
\hline
\end{tabular}


salience in the traditional mainstream media and political participation $(\beta=0.192$, $p<0.001$ ), supporting H1. Secondly, the positive relationship between salience in social media and political participation was endorsed $(\beta=0.319, \mathrm{p}<0.001)$, supporting H2. Thirdly, we hypothesized a positive association between political participation and political trust, and our data supported it ( $\beta=0.136, p<0.001)$. Finally, we further confirmed that the $\mathrm{Q}^{2}$ values for political participation $\left(\mathrm{Q}^{2}=0.111\right)$ and political trust $\left(\mathrm{Q}^{2}=0.146\right)$ were $\mathrm{s}$ greater than 0 (Hair et al., 2014), suggesting that the model has sufficient predictive relevance. With respect to the effect size $\left(\mathrm{f}^{2}\right)$, it could be seen in Table 5 that the effect size ranged from medium to large, which resonated with the threshold of Cohen (1988).
Preacher and Hayes $(2004,2018)$ noted that we adopted bootstrapping method to test the indirect effect, Based on Table 6, we found the indirect effect between salience in mainstream media and political trust $(\beta=$ $0.336, p=0.000)$ and between social media and political trust $(\beta=0.297, p=0.000)$ were significant. For the indirect effects at 97.5\% Bootstrapping Confidence Level Bias Correction (BC) assessment, we found that there was no 0 value in between lower limit and upper limit $(\mathrm{LL}=0.245, \mathrm{UL}=0.412)$, $(\mathrm{LL}=0.218, \mathrm{UL}=0.381)$. The results suggest a significant mediation. Political participation was a significant mediator that affected the relationship between salience in media (for both mainstream media and social media contexts) and political trust. Hence, both H4 and H5 were supported.

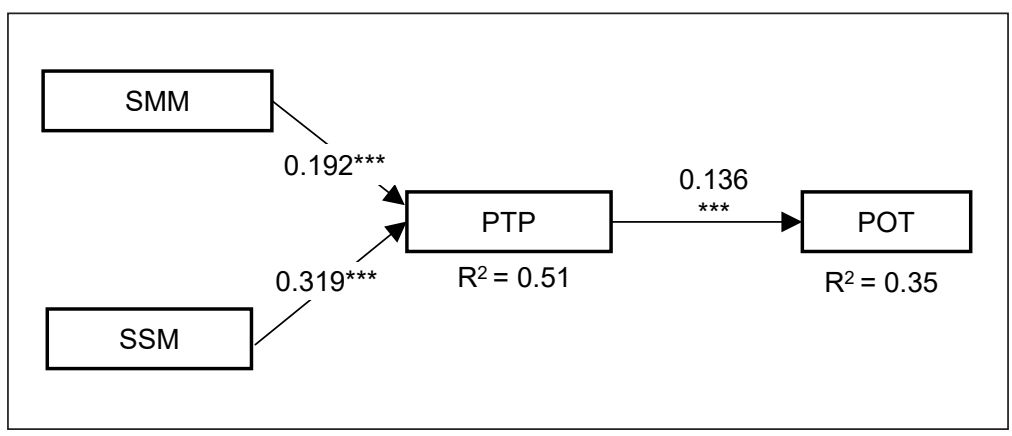

Figure 2. The structural model

Table 5

Direct relationships

\begin{tabular}{lcccccccccc}
\hline Path Analysis & Beta & S.E. & t-value & p-value & LCI & UCI & R2 & f2 & Q2 & Decision \\
\hline SMM -> PTP & 0.192 & 0.043 & 4.505 & 0.000 & 0.110 & 0.275 & & 0.234 & & Supported \\
SSM -> PTP & 0.319 & 0.041 & 7.806 & 0.000 & 0.237 & 0.397 & 0.51 & 0.382 & 0.146 & Supported \\
PTP -> Political & 0.136 & 0.035 & 3.870 & 0.000 & 0.199 & 0.269 & 0.35 & 0.162 & 0.111 & Supported \\
Trust & & & & & & & & & &
\end{tabular}

NB: $\mathrm{SSM}=$ Salience in the Social Media; $\mathrm{SMM}=$ Salience in the Traditional Mainstream Media, $\mathrm{PTP}=$ Political Participation, $\mathrm{LCI}=2.5 \%$, UCI $=97.5 \%$. 
Table 6

Indirect (mediating) relationships

\begin{tabular}{lccccccc}
\hline Path Analysis & Beta & S.E. & t-value & p-value & LI & CI & Decision \\
\hline SMM -> PTP -> Political Trust & 0.336 & 0.077 & 7.161 & 0.000 & 0.245 & 0.412 & Supported \\
SSM -> PTP-> Political Trust & 0.297 & 0.058 & 6.474 & 0.000 & 0.218 & 0.381 & Supported \\
\hline
\end{tabular}

Note $: \mathrm{SSM}=$ Salience in the Social Media; $\mathrm{SMM}=$ Salience in the Traditional Mainstream Media, $\mathrm{LCI}=$ $2.5 \%, \mathrm{PTP}=$ Political Participation, $\mathrm{UCI}=97.5 \%$.

\section{DISCUSSION}

This study affirmed the general postulation that the media, as the information provider of political and current affairs news, is crucial to the democratic development of any democratic nation (Camaj, 2014; Ceron, 2015), especially for a nation with a nascent democracy like Nigeria. Contrary to the cynics, the general results of this study show that both traditional mainstream media and social media are generally indispensable to democratic development and political outcomes. It is because the media is essential to influence citizens' perception of government activities. Furthermore, it corroborates the suggestions of previous studies in Allen (2016), Camaj (2014), and Ceron (2015) that the audience accumulates political knowledge, which is germane to political trust through media exposure.

This study argues that media can shape and influence people's opinions, attitudes and behavior by salience to selected issues. Focusing on how people perceive the salience of corruption in traditional media and social media, this study found that perceived salience in both media contexts has positive effects on political participation and political trust. This outcome supports our hypotheses 1 and 2. The significant relationship between these constructs indicates that traditional mainstream media and social media can enrich people's political knowledge that affects their political behavior. It further shows that mainstream media and social media complement each other, rather than working at cross purposes (Albarran \& Moellinger, 2013; Mare, 2013). In this sense, both media types can increase public awareness about corruption and increase people's political participation and trust.

Furthermore, affirming the existing studies on the relationship between political participation and political trust (Jacob \& Schenke, 2020; Wilkes, 2015), this study demonstrates the high relevance of political participation to political trust. It thus emphasizes that political participation is a strong predictor of political trust in Nigeria. It supports our H3. Moreover, we treated political participation as a mediating variable in this study to reveal its indirect effect on political trust. Political participation was found to be a significant mediator. Our findings suggest that the media exerts its influence on political participation, affecting political trust. Thus, $\mathrm{H} 4$ and $\mathrm{H} 5$ were supported. When comparing the results of direct and indirect effects, we found a higher increase in political trust when political participation mediated the relationship in traditional mainstream media 
than social media contexts. Our findings have theoretical and practical implications.

\section{Theoretical Implications}

Previous studies identify the perception of corruption, political performance, and economic performance as determinants of political trust (Drakos et al., 2019; Murtin et al., 2018; Wang, 2016), but this study identified media salience as one of the crucial determinants of political trust. The incorporation of media as a strong predictor of political trust showed the importance of media in restoring people's trust in their government. Furthermore, political participation is also a mediating variable and significant determinant of political trust in Nigeria.

Also, this study contributed to the theoretical advancement of the concept of political trust. The previous study adopted media malaise and virtuous theories to predict that mass media will cause political alienation by fueling citizens' cynicism (Cheng, 2020; Marien, 2017). However, in this study, the theories of agenda-setting and agenda-melding were employed to explain media influence on political trust. Combining the two theoretical lenses is unique since no study on the political outcome has combined the two theories in a study. It has therefore enhanced the richness and interconnectivity effects of the two theories in this study. This study also fills the gap in the previous studies by demonstrating that both agenda-setting and agenda-melding theories operating in different contexts act together to impact political trust.

\section{Practical Implications}

The study provides some insights on the important role of the media in restoring trust towards the government by assigning salience to important issues in society. Our findings can help the government develop effective media strategies to address the problem of low political participation and low political trust among the people, especially among the younger generations. To achieve this, the government should utilize both traditional mainstream media and social media to reach out to the people. One of the ways is by leveraging on national issues, such as corruption, affecting so many people in Nigeria. In doing so, media can serve as a tool to attract people to participate in politics. Harnessing on the indispensable roles of media in priming, framing, and giving salience to important issues in society, both mainstream media and social media in Nigeria can act as catalysts of change in society by fostering active participation in politics among the people and hence increasing their trust in the incumbent government.

\section{CONCLUSION}

Our study is set to uncover the role of different media types (i.e., traditional mainstream media and social media) in influencing political participation and political trust in Nigeria. We found support for all hypotheses in our study. We concluded that traditional mainstream media and social media significantly affect political participation in Nigeria because they strengthen citizens' political knowledge 
and motivate efficient media information processing by giving salience on certain issues over others. In other words, it allows Nigerians to become more knowledgeable and develop their stance on political issues. Our study found that greater salience given to political media content increases citizens' participation in politics and subsequently increases political trust. In this study, we also confirm the direct link between political participation and political trust. The key factor in increasing political trust in Nigeria is participation in politics. When people are alert and active, they are motivated to participate in many activities and committed to programs and policies that bring more development. These activities lead to trust in the government. Future research should examine the types of political participation that can enhance political trust further to understanding the dyadic relationships between media and politics.

\section{ACKNOWLEDGEMENTS}

The authors would like to thank the Federal Polytechnic Ede and the Tertiary Education Trust Fund (TETFund) Nigeria for granting the scholarship that makes this paper possible.

\section{REFERENCES}

Aarts, K., Fladmoe, A., \& Strömbäck, J. (2012). Media, political trust, and political knowledge: A comparative perspective. In How media inform democracy (pp. 112-132). Routledge.

Albarran, A. B., \& Moellinger, T. (2013). Traditional media companies in the US and social media: What's the strategy? In Handbook of social media management (pp. 9-24). Springer.
Allen, L. P. (2016). College students' trust in government, interpersonal trust, Facebook usage, and political efficacy (Master's thesis). University of Louisiana.

Baltar, F., \& Brunet, I. (2012). Social research 2.0: Virtual snowball sampling method using Facebook. Internet Research, 22(1), 57-74. https://doi.org/10.1108/10662241211199960

Bantimaroudis, P., Sideri, M., Ballas, D., Panagiotidis, T., \& Ziogas, T. (2020). Conspiracism on social media: An agenda melding of group-mediated deceptions. International Journal of Media \& Cultural Politics, 16(2), 115-138. https://doi. org/10.1386/macp_00020_1

Berg, L. (2019). Citizens 'trust in trust in the European Union in challenging times. Palgrave Macmillan. https://doi.org/10.1111/jcms.12558

Bonifácio, R., \& Paulino, R. (2015). Corruption and political participation in the Americas and the Caribbean. Brazilian Political Science Review, 9(2), 54-80. https://doi.org/10.1590/198138212014000200011

Camaj, L. (2014) The media's role in fighting corruption: Media effects on governmental accountability. The International Journal of Press/Politics, 18(1), 21-42. https://doi. org/10.1177/1940161212462741

Ceron, A. (2015). Internet, news, and political trust: The difference between social media and online media outlets. Journal of Computer-Mediated Communication, 20(5), 487-503. https://doi. org/10.1111/jcc4.12129

Ceron, A., \& Memoli, V. (2016). Flames and debates: Do social media affect satisfaction with democracy? Social Indicators Research, 126(1), 225-240. https://doi.org/10.1007/s 11205-0150893-x

Cheng, X. (2020). Malaise effect or virtuous effect? The dynamics of internet use and political trust in China. International Journal of Communication, 14(1), 1-22 
Cheng, Y. (2021). Maxwell McCombs and Sebastián Valenzuela, setting the agenda: Mass media and public opinion. International Journal of Communication, 15(3), 1712-1714

Cohen, J. (1988). Statistical power analysis for the behavioral sciences (2nd ed.). Lawrence Erlbaum Associates Publishers.

Dagona, Z. K., Karick, H., \& Abubakar, F. M. (2013). Youth participation in social media and political attitudes in Nigeria. Journal of Sociology, Psychology and Anthropology in Practice, 5(1), 1-7.

Drakos, K., Kallandranis, C., \& Karidis, S. (2019). Determinants of trust in institutions in times of crisis: Surveybased evidence from the European Union. Journal of Common Market Studies, 57(6),1228-1246. https://doi.org/10.1111/ jcms. 12884

Echeverría, M., \& Mani, E. (2020). Effects of traditional and social media on political trust. Communication \& Society, 33(2), 119-135. https://doi.org/10.15581/003.33.2.119-135.

Färdigh, M. A. (2013). What's the use of a free media? The role of media in curbing corruption and promoting quality of government [Ph.D. dissertation, University of Gothenburg]. http:// hdl.handle.net/2077/34302

Fornell, C., \& Larcker, D. F. (1981). Evaluating structural equation models with unobservable variables and measurement error. Journal of Marketing Research, 18(1), 39-50. https://doi. org/10.2307/3151312.

Gil de Zúñiga, H., Molyneux, L., \& Zheng, P. (2014). Social media, political expression, and political participation: Panel analysis of lagged and concurrent relationships. Journal of Communication, 64(4), 612-634. https://doi. org/10.1111/jcom. 12103

Hair Jr, J. F., Sarstedt, M., Hopkins, L., \& Kuppelwieser, V. G. (2014). Partial least squares structural equation modeling (PLS-SEM). European Business Review, 26(2), 106-121. https:/doi. org/10.1108/EBR-10-2013-0128

Hair, J. F., Risher, J. J., Sarstedt, M., \& Ringle, C. M. (2019). When to use and how to report the results of PLS-SEM. European Business Review, 31(1), 2-24. https://doi.org/10.1108/EBR-112018-0203

Hair, J., Hollingsworth, C. L., Randolph, A. B., \& Chong, A. Y. L. (2017). An updated and expanded assessment of PLS-SEM in information systems research. Industrial Management \& Data Systems, 117(3). 442-458. https://doi. org/10.1108/IMDS-04-2016-0130

Hänggli, R. (2020). Flow of frames: In the origin of dialogue in the news media. Palgrave Macmillan. https://doi.org/10.1007/978-3-030-26582-3_7

Hetherington, M. (1998). The political relevance of trust. American Political Science Review, 92(4), 791-808. https://doi.org/10.2307/2586304

Huddy, L., Mason, L., \& Aarøe, L. (2010, July 7-10). Measuring partisanship as a social identity, predicting political activism. Annual Meeting of the International Society for Political Psychology, Arhus University, San Francisco, CA, USA.

Iroghama, P. I. (2012). Trust in government: A note from Nigeria. International Journal of Academic Research in Economics and Management Sciences, 2(1), 258-267.

Jacob, M. S., \& Schenke, G. (2020). Partisanship and institutional trust in Mongolia. Democratization, 27(4), 605-623. https://doi.org/10.1080/135103 47.2019.1711060

Kiousis, S. (2004). Explicating media salience: A factor analysis of New York Times issue coverage during the 2000 US presidential election. Journal of Communication, 54(1), 7187. https://doi.org/10.1111/j.1460-2466.2004. tb02614.x 
Kiousis, S. (2011). Agenda-setting and attitudes: Exploring the impact of media salience on perceived salience and public attitude strength of us presidential candidates from 1984 to 2004. Journalism Studies, 12(3), 359-374. https://doi. org/10.1080/1461670X.2010.501149

Kleinnijenhuis, J., Hartmann, T., Tanis, M., \& van Hoof, A. M. (2020). Hostile media perceptions of friendly media do reinforce partisanship. Communication Research, 47(2), 276-298. https://doi.org/10.1177/0093650219836059

Krishna, S., \& Jha, S. (2017) An assessment of the agenda between new media and traditional mainstream mass media. Journal of Advances and Scholarly Researches in Allied Education, 12(2), 103-108.

Kumar, D., Pratap, B., \& Aggarwal, A. (2020). Public trust in state governments in India: Who are more confident and what makes them confident about the government? Asian Journal of Comparative Politics, 20(10), 1-21. https:// doi.org/10.1177/2057891119898763

Mare, A. (2013). A complicated but symbiotic affair: The relationship between mainstream media and social media in the coverage of social protests in southern Africa. Ecquid Novi: African Journalism Studies, 34(1), 83-98. https://doi.org $/ 10.1080 / 02560054.2013 .767426$

Marien, S. (2017). Assessing the role of television, the family, and the school in the development of political trust in adolescence. Social Science Quarterly, 98(3), 818-835. https://doi. org/10.1111/ssqu. 12433

McCombs, M. E., \& Shaw, D. L. (1972). The agenda-setting function of mass media. Public Opinion Quarterly, 36(2), 176-187.https://doi. org/10.1086/267990

McCombs, M. E., Shaw, D. L., \& Weaver, D. H. (2014). New directions in agenda-setting theory and research. Mass Communication and Society, 17(6), 781-802.
Murtin, F., Fleischer, L, Siegerink, V., Aassve, A., Algan, Y., Boarini, R., González, S., Lonti, Z., Gianluca, G., Vallve, R.H., Kim, S., Lee, D., Putterman, L., \& Smith, C. (2018). Trust and its determinants: Evidence from the Trustlab experiment [OECD Statistics Working Papers, 2018/02]. OECD Publishing. http://dx.doi. org/10.1787/869ef2ec-en

Mustapha, L. K., \& Omar, B. (2020). Do social media matter? Examining social media use and youths' political participation during the 2019 Nigerian general elections. The Round Table, 109(4), 441-457. https://doi.org/10.1080/00358533.20 20.1788766

Mustapha, L. K., \& Wok, S. (2015). Exploring the agenda-setting potential of homeland online newspapers on perceptions of elections issues among diasporic Nigerians in Malaysia. Intellectual Discourse, 23(2) 275-298.

National Bureau of Statistics. (2017). Demographic statistics bulletin. https://africaopendata. org/dataset/demographic-statistics-bulletinnigeria-2017

Newton, K., Stolle, D., \& Zmerli, S. (2018). Social and political trust. In The Oxford handbook of social and political trust. Oxford University Press.

Ogbeidi, M. M. (2012). Political leadership and corruption in Nigeria since 1960: A socioeconomic analysis. Journal of Nigeria studies, 1(2), 1-25.

Okafor, O. N., Adebisi, F. A., Opara, M., \& Okafor, C. B. (2020). Deployment of whistleblowing as an accountability mechanism to curb corruption and fraud in a developing democracy. Accounting, Auditing \& Accountability Journal, 33(6), $1335-1336$

Omar, B. (2017). Online news production, consumption and immediacy: The remediation perspective. Jurnal Komunikasi: Malaysian Journal of Communication, 33(3), 250-266. 
Omar, B., \& Ahrari, S. (2020). Mainstream and nonmainstream media in Malaysia: Does lack of credibility lead to displacement? Newspaper Research Journal, 41(2), 127-145. https://doi. org/10.1177/0739532920919825

Park, S. Y. (2012). The effects of message framing and risk perceptions for HPV vaccine campaigns: Focus on the role of regulatory fit. Health Marketing Quarterly, 29(4), 283-302. https://doi. org/10.1080/07359683.2012.732847

Preacher, K. J., \& Hayes, A. F. (2004). SPSS and SAS procedures for estimating indirect effects in simple mediation models. Behavior Research Methods, Instruments \& Computers, 36(4), 717731. https://doi.org/10.3758/BF03206553

Preacher, K. J., \& Hayes, A. F. (2008). Asymptotic and resampling strategies for assessing and comparing indirect effects in multiple mediator models. Behaviour Research Methods, 40(3), 879-891. https://doi.org/10.3758/BRM.40.3.879

Ragas, M. W., \& Roberts, M. S. (2009). Agenda setting and agenda melding in an age of horizontal and vertical media: A new theoretical lens for virtual brand communities. Journalism \& Mass Communication Quarterly, 86(1), 45-64. https:// doi.org/10.1177/107769900908600104

Ramayah, T., Cheah, J., Chuah, F., Ting, H., \& Memon, M. A. (2018). Partial least squares structural equation modeling (PLS-SEM) using SmartPLS 3.0. In An updated guide and practical guide to statistical analysis. Pearson.
Schneider, I. (2017). Can we trust measures of political trust? Assessing measurement equivalence in diverse regime types. Social Indicators Research, 133(3), 963-984. https:// doi.org/10.1007/s11205-016-1400-8

Shahzad, S., \& Omar, B. (2021). Social network matters: The influence of online social capital on youth political participation in Pakistan. Journal of Information Technology \& Politics, 18(4), 430-442 https://doi.org/10.1080/19331681.20 21.1900018

Skamnakis, A. (2006). Politics, media and journalism in Greece [Doctoral dissertation]. Dublin City University.

Siapera, E. (2017). Understanding new media. Sage.

Wang, C. H. (2016). Government performance, corruption, and political trust in East Asia. Social Science Quarterly, 97(2), 211-231. https://doi. org/10.1111/ssqu.12223

Wilkes, R. (2015). We trust in government, just not in yours: Race, partisanship, and political trust, 1958-2012. Social Science Research, 49(3), 356-371. https://doi.org/10.1016/j. ssresearch.2014.08.008

Woo, C. W., Brigham, M. P., \& Gulotta, M. (2020). Twitter talk and Twitter sharing in times of crisis: Exploring rhetorical motive and agenda-setting in the ray rice scandal. Communication Studies, 71(1), 40-58. https:// doi.org/10.1080/10510974.2019.1661866 
